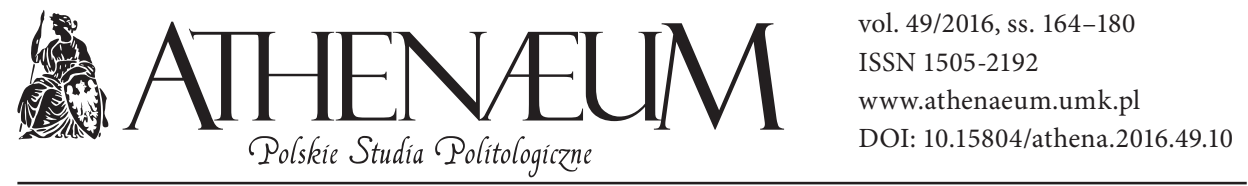

\title{
WSPÓŁPRACA MIĘDZYNARODOWA GMINY MIEJSKO-WIEJSKIEJ. PRZYPADEK OLECKA
}

\author{
INTERNATIONAL COOPERATION \\ OF URBAN-RURAL BOROUGH. OLECKO CASE STUDY
}

Stanisław Faliński*

\begin{abstract}
ABSTRAKT
Artykuł jest studium przypadku, przedstawiającym współpracę międzynarodową Olecka, które jest stolicą Mazur Garbatych, jako jednej z ponad sześciuset istniejących w Polsce gmin miejsko-wiejskich. Ukazano w nim sięgające czasów komunistycznej Polski początki tej współpracy, wyrażającej się kooperacją z francuską gminą Marly. Główna część tekstu stanowi omówienie ewolucji i ocenę współczesnej współpracy międzynarodowej Olecka, na którą składają się relacje z partnerami białoruskimi (Szczuczyn), litewskimi (Wilkowyszki, Kozłowa Ruda), ukraińskimi (Drohobycz), rosyjskimi (Gusiew), austriackimi (Guessing) i estońskimi (Johvi). Cechą charakterystyczną aktywności międzynarodowej Olecka jest ścisłe powiązanie $\mathrm{z}$ jego położeniem geograficznym i pochodzeniem olecczan. To one determinują $\mathrm{w}$ przeważającym stopniu, z kim i na jakich zasadach miasto współpracuje, w bardzo znaczącym stopniu wykorzystując fundusze Unii Europejskiej. Ta aktywność stolicy Mazur Garbatych została dostrzeżona na arenie międzynarodowej. W roku 2014 Olecko zostało uhonorowane prestiżową nagrodą i tytułem Europejskiego Miasta Sportu.
\end{abstract}

ABSTRACT

The article is a case study which depicts the international cooperation of Olecko, which is the capital of Mazury Garbate and one of over six hundred urban-rural boroughs in Poland. It shows the beginnings of this activity, dating back to the communist times in Poland, expressed through cooperation with the French municipality of Marly. The main part of the text, however, discusses the evolution and evaluation of contemporary international cooperation of Olecko, which consists in developing relations with Belarusian (Szczuczyn), Lithuanian (Wilkowyszki, Kozlov Ore), Ukrainian (Drohobych), Russian (Gusev), Austrian (Guessing), and Estonian (Johvi) partners. A characteristic feature of Olecko's international activity is closely linked with its geographical position and the origin of its inhabitants. These factors largely determine with whom and on what terms the city cooperates with, using a significant amount of EU funding. This international activity of the capital of Mazury Garbate has been internationally recognized. In 2014, Olecko was awarded the prestigious prize and the European City of Sport title.

\footnotetext{
* Collegium Civitas w Warszawie.
} 
Słowa kluczowe: samorząd terytorialny, gmina, współpraca międzynarodowa, Olecko
Keywords: Local self-government, international cooperation, borough, Olecko

\section{WSTĘP}

Artykuł ten stanowi studium konkretnego przypadku, a jego celem jest przedstawienie współpracy międzynarodowej Olecka, jako jednej z ponad 600 polskich gmin miejsko-wiejskich, czyli gmin, których stolica znajduje się w mieście, zaś na gminę składają się jeszcze wsie i obszary wiejskie. Poza warstwą faktograficzną podjęto w tekście próbę udzielenia odpowiedzi na pytanie: co i w jakim stopniu zdecydowało o takim kształcie współpracy międzynarodowej tej konkretnej, typowej, ale mającej swoją specyfikę gminy. Olecko nie należy w tej grupie jednostek samorządu terytorialnego ani do największych, ani do najmniejszych. Jest średniej wielkości, zarówno po względem powierzchni (zajmuje $266 \mathrm{~km}^{2}$ ), jak i ludności (ponad 22 tysiące mieszkańców). Jej położenie jest specyficzne, leży bowiem w północno-wschodnim krańcu Polski, a granicę z Rosją czy Białorusią dzieli tylko kilkadziesiąt kilometrów. Dla zrealizowania przedstawionego celu i rozwiązania postawionego $\mathrm{w}$ formie pytania problemu badawczego wykorzystano przede wszystkim wytworzone lokalnie, przez aparat administracyjny omawianej gminy, źródła pisane, jak również źródła wywołane i powstałe specjalnie na potrzeby niniejszego artykułu: rozmowy - wywiady autora $z$ burmistrzem i jego zastępcą - oraz pisemne opracowanie przygotowane przez urzędniczkę gminną według schematu określonego zestawem pytań sformułowanych przez piszącego te słowa (Mieszuk, 2015). Posiłkowo wykorzystano literaturę ogólną i teoretyczną poświęconą problematyce współpracy międzynarodowej samorządów terytorialnych.

Współpraca międzynarodowa Olecka jako wspólnoty mieszkańców i struktury administracyjnej ma tradycje sięgające okresu Polski Ludowej, kiedy samorząd terytorialny nie istniał i cała władza publiczna była zbudowana hierarchicznie. Decyzje o podjęciu takiej współpracy przez poszczególne elementy tej struktury musiały być akceptowane - a często były podejmowane - przez wyższe, w stosunku do nawiązującej tę współpracę jednostki administracyjnej, szczeble tej konstrukcji. Całością i poszczególnymi jej składnikami kierowała rządząca 
ówczesną Polską partia komunistyczna, czyli Polska Zjednoczona Partia Robotnicza. Nie przesądzało to jednak o tym, że w tej scentralizowanej z założenia strukturze nie było miejsca dla inicjatyw lokalnych. Dowodzą tego podpisane w okresie PRL umowy pomiędzy miastami polskimi i zagranicznymi. Tak też było w przypadku będącego przedmiotem naszego zainteresowania Olecka.

Pierwsze porozumienie $\mathrm{z}$ partnerem zagranicznym miasto to podpisało na początku lat 70. ubiegłego wieku, kiedy po dojściu do władzy pierwszego sekretarza PZPR Edwarda Gierka w znacznie większym stopniu niż wcześniej Polska otworzyła się na zagranicę, przede wszystkim na tak zwany Zachód. Zgodnie z planami ówczesnych przywódców komunistyczna Polska Rzeczpospolita Ludowa miała się modernizować we współpracy z państwami Europy Zachodniej oraz innymi krajami demokratycznymi i kapitalistycznymi. Szczególna rola w tym procesie miała przypaść Francji jako państwu, z którym poprzez swój życiorys był związany Gierek oraz które prowadziło politykę nastawioną na współpracę pomiędzy komunistycznym Wschodem a Zachodem. Znalazło to swój wyraz także we współpracy polskich i francuskich wspólnot oraz władz lokalnych, w tym Olecka.

21 listopada 1971 roku Olecko nawiązało współpracę z miasteczkiem Marly, leżącym w północno-wschodniej Francji, niedaleko granicy z Belgią (Mieszuk, 2015). Bezpośrednim inicjatorem tego porozumienia był emigrant z Polski, olecczanin, który doprowadził do porozumienia swojej starej, polskiej małej ojczyzny z nowa, francuską. Wykorzystał więc - prawdopodobnie nieświadomie - właśnie powstałą, sprzyjającą koniunkturę na współpracę polsko-francuską. W cztery lata później związek ten potwierdzono podpisaniem 26 listopada 1975 roku oficjalnego porozumienia. Ze strony francuskiej podpisał je mer Marly, Guy Ville, a ze strony polskiej Przewodniczący Rady Narodowej Olecka, Piotr Domel. Dokument ten, w charakterystycznym dla swojej epoki języku, określał cele współpracy:

„a) zacieśnienie kontaktów polsko-francuskich,

b) wymiana doświadczeń,

c) zacieśnienie kontaktów w specjalistycznych zagadnieniach interesujących obie strony,

d) wymianę delegacji ogólnych i branżowych oraz inne formy bezpośrednich kontaktów,

e) organizację specjalistycznych imprez w obydwu miastach".

Określono także metody i formy realizowania założonych celów. Miały nimi być organizowane w obu miastach wystaw prac fotograficznych i graficznych współpracujących miast, przekazanie przez Marly bibliotece oleckiej literatury 
i podręczników do nauki języka francuskiego, powołanie w Olecku towarzystwa polsko-francuskiego, wyjazdy na wymianę dzieci i młodzieży w okresie ferii, a także „wymiana delegacji ogólnych miasta”, czyli wzajemne wizyty przedstawicieli władz obu miast czy osób, bądź instytucji przez te władze wskazanych. Zawarte w tym dokumencie zapisy były sukcesywnie realizowane i rozwijane. Pojawiła się jednak konieczność przeglądu dotychczasowej współpracy oraz jej podsumowania i dopracowania. W dziesięć lat po nawiązaniu współpracy - 17 maja 1980 roku - oba miasta podpisały kolejne porozumienie, w którym dookreślano formy już realizowanej współpracy. Co ciekawe, $\mathrm{z}$ francuskiej strony zostało ono podpisane przez tego samego urzędnika co poprzednio. Podpisane jeszcze w czasach PRL porozumienia międzynarodowe są realizowane do dzisiaj.

Jeszcze w latach 70. ubiegłego wieku rozpoczęły się wymiany młodzieży. Początkowo miały one charakter wakacyjny, kiedy odwiedzały się wzajemnie liczące od kilkunastu do dwudziestu uczestników grupy dzieci i młodzieży, którym towarzyszyli wychowawcy. Z czasem pojawiły się wizyty młodych ludzi w domach ich zagranicznych rówieśników. To szczególnie cenna forma wymiany i zapoznawania się ludzi z różnych krajów. Dzięki niej można się rzeczywiście poznać i pozbyć negatywnych stereotypów, a w efekcie zaprzyjaźnić. Wizyty Olecczan w Marly - nie tylko młodzieży, ale także przedstawicieli różnych, innych środowisk zawodowych i społecznych - skutkowały nie tylko poznawaniem zaprzyjaźnionego miasta i jego mieszkańców, ale także zwiedzaniem Paryża czy Lille, doskonaleniem języka francuskiego i poznawaniem kultury francuskiej. To samo dotyczyło odwiedzających Olecko i Polskę Francuzów, którzy poznawali naszą kulturę i język, zwiedzali miasta i oglądali zabytki, odpoczywali wśród unikatowej przyrody Mazur Garbatych. Szczególną rolę w poznawaniu się współpracujących społeczności lokalnych obu miast spełniały i spełniają różnego rodzaju wystawy i koncerty organizowane $\mathrm{z}$ okazji świąt francuskich i polskich (Mieszuk, 2015). Ogniskowanie się wzajemnych kontaktów wokół rocznic pozwala Francuzom poznać naszą tradycję historyczną, a nam francuską. Stwarza to także okazję do uświadomienia sobie bliskości i pokrewieństwa kulturowo-historycznego obu europejskich narodów. Specjalne miejsce podczas tego typu wydarzeń odgrywają biorące w nich udział szkoły muzyczne. Młodzi muzycy ze strony polskiej i francuskiej oddziałują wzajemnie na siebie, budując więź sympatii, ale także upowszechniają kulturę polską we Francji, a francuską w Polsce. Pomagają uświadomić sobie wzajemnie i członkom swoich wspólnot lokalnych europejskie pokrewieństwo kulturowe mieszkańców Olecka i Polski z mieszkańcami Marly i Francji. 
Swoistym fenomenem stosunków Olecka z Marly jest ich trwałość oraz odporność na przemiany ustrojowe, gdyż są one utrzymywane od ponad 40 lat. Rozpoczęły się w czasach głębokiego, choć starającego się modernizować, komunizmu. Rozwijały się intensywnie w tych czasach i jako takie weszły w czasy niepodległej Polski, w której się umocniły. Ta trwałość i odporność na przemiany ustrojowe zdaje się świadczyć o tym, że budowanie współpracy i sympatii pomiędzy różniącymi się ludźmi jest znacznie łatwiejsze poprzez współpracę wspólnot lokalnych i samorządów terytorialnych, niż poprzez nastawione na walkę i konkurencję państwa narodowe (Barber, 2014).

Tę kooperatywność Olecka i jego specyficznie bliskie związki z Marly potwierdza także uczestnictwo obu tych gmin w swego rodzaju mikrosieci samorządowej. Są one bowiem współzałożycielami porozumienia pięciu gmin z różnych państw Unii Europejskiej: Lepe (Hiszpania), Marly (Francja), Olecko (Polska), Valmiera (Łotwa), Vilkaviskis (Litwa). Do założenia tej luźnej struktury doszło 13 lipca 1998 roku w Marly poprzez podpisanie „aktu połączenia i współpracy zdecentralizowanej" (Mieszuk, 2015). Powstawanie tego typu ugrupowań samorządów terytorialnych poza i ponad państwami dowodzi ich chęci i woli wzajemnej współpracy. Potwierdza także większą otwartość samorządów terytorialnych na wymianę i współpracę niż mają z definicji stwarzające bariery państwa narodowe.

Kolejne porozumienie międzynarodowe Olecka jest jednym z wielu wynikających z tego, że miasto po drugiej wojnie światowej było w przeważającej części zasiedlane przez Polaków przybyłych z różnych części przedwojennej i powojennej Polski, niejako okalających Mazury Garbate i jego stolicę od południa, wschodu i północnego wschodu. Olecczanami stawali się w większości ludzie przybyli z Białostocczyzny, Suwalszczyzny, Wileńszczyzny i z Grodzieńszczyzny. Jeden $\mathrm{z}$ nich, repatriant z białoruskiego Szczuczyna, wyszedł z inicjatywą nawiązania współpracy jego niegdyś rodzinnego miasta z Oleckiem (rozmowa przeprowadzona przez autora z burmistrzem Olecka Wacławem Olszewskim 19.10.2015 roku). Umowę podpisano 7 listopada 1993 roku w Szczuczynie.

Punktem wyjścia dokumentu było jego wpisanie się w szeroki kontekst stosunków polsko-białoruskich, realizowanych na poziomie państwowym i narodowym. Co istotne, podkreślano, że stosunki te mają być przyjazne. Ich celem miało być wspieranie i organizowanie wzajemnych wymian mieszkańców. Miały dotyczyć kultury, sportu, nauki, spraw technicznych oraz problemów pracowniczych różnych środowisk zawodowych. Planowano dzielić się doświadczeniami i umiejętnościami, a także współdziałać w tym zakresie. Specjalne 
miejsce poświęcono problematyce gospodarczej. Zamierzano doprowadzić do podjęcia wzajemnie korzystnej współpracy przez znajdujące się na terenie obu miast podmioty gospodarcze. Co znamienne, w dokumencie tym znalazł się zapis dotyczący problemów ideowo-politycznych, pozostających teoretycznie poza głównym nurtem współpracy municypalnej. W odpowiednim artykule omawianej umowy możemy na ten temat przeczytać: „Miasta zobowiązują się do respektowania ich odrębności i realiów bez ingerencji politycznej, filozoficznej i religijnej”. Wydaje się, iż taki zapis wynikał z obawy Białorusinów o swoistą indoktrynację ze strony polskiej (miał on przed nią zabezpieczać?). Polska strona zadeklarowała w tym dokumencie szczególne zainteresowanie zamieszkującymi Szczuczyn środowiskami polonijnymi.

Realizacja umowy Olecko-Szczuczyn była zdominowana przez problematykę polonijną. Także dzięki współpracy określonej tym porozumieniem i zabiegom ze strony władz Olecka otwarto w Szczuczynie Dom Polaków. W jego otwarciu uczestniczyła delegacja stolicy Mazur Garbatych. Było to duże wydarzenie nie tylko dla Polaków zamieszkujących Szczuczyn, ale także tych mieszkających w Olecku, a mających korzenie szczuczyńskie. Inni olecczanie również angażowali się w pomoc rodakom zamieszkującym Szczuczyn. Organizowano pomoc rzeczową dla zamieszkujących to białoruskie miasto rodaków, dostarczając paczki z odzieżą, żywnością, książkami i materiałami piśmiennymi dla dzieci i młodzieży. Jedna z młodych osób pochodzenia polskiego zamieszkujących Szczuczyn otrzymała stypendium umożliwiające studia we Wszechnicy Mazurskiej, działającej w latach 1992-2013 oleckiej niepublicznej uczelni. Niestety, po paru latach od podpisania umowy kontakty Olecko-Szczuczyn przestały być realizowane (Mieszuk, 2015). Był to częściowo efekt polityki prowadzonej przez prezydenta Łukaszenkę.

Kolejna międzynarodowa umowa Olecka została zawarta z litewskim Vilkaviskis (Wilkowyszki), także mającym długoletnie związki z polskością. Podpisano ją 31 maja 1996 roku (współpraca pomiędzy władzami obu miast istniała jeszcze w czasach komunistycznych i sięga lat 70. XX wieku). Treść umowy jest niemal identyczna w stosunku do tej podpisanej ze Szczuczynem, włącznie z cytowanym wcześniej passusem dotyczącym spraw ideowo-politycznych. Można przyjąć, że Litwinami kierowały w tej sprawie podobne motywacje jak Białorusinami. Nie znajdziemy w umowie z Wilkowyszkami fragmentu dotyczącego szczególnego zainteresowania Olecka środowiskami polonijnymi.

W początkowym okresie obowiązywania tego porozumienia jego wymiar praktyczny ograniczał się do wzajemnych wizyt oficjalnych delegacji i wymian 
środowiskowych. Nowego wymiaru nabrało ono po wejściu obu państw do Unii Europejskiej, szczególnie zaś w perspektywie finansowej 2007-2013, która jest realizowana do końca 2015 roku. Oba samorządy podjęły współpracę mającą na celu wspólne aplikowanie dotyczące środków na realizowane razem projekty w ramach unijnego Programu Współpracy Transgranicznej Litwa-Polska. Efektem tej współpracy było zrealizowanie przez Olecko wielu projektów finansowanych w zdecydowanej większości ze środków unijnych. W roku 2010 Regionalny Ośrodek Kultury w Olecku „Mazury Garbate” realizował wspólnie z Centrum Dzieci i Młodzieży w Wikowyszkach projekt noszący nazwę „Polsko-litewskie spotkania z tańcem i folklorem. Tradycja - współczesność.” W jego ramach organizowano $\mathrm{w}$ obu miastach warsztaty, prezentacje sceniczne, spotkania integracyjne. Na Litwie odbywały się one pod hasłem „Spotkania z tańcem”, zaś w Polsce nosiły nazwę „Mazurskie spotkania z folklorem”. Kolejny program realizowano w szerszym, samorządowym gronie. Do Olecka i Wilkowyszek dołączył polski Orzysz i litewski rejon Alytus. Razem, w latach 2009-2011, realizowano przedsięwzięcie noszące nazwę „Transgraniczna współpraca młodzieży”. Rozbudowano i udoskonalono istniejącą oraz stworzono nową infrastrukturę sportową, zakupiono sprzęt sportowy, a także przeprowadzono szereg integrujących młodzież z obu krajów imprez i zawodów sportowych. Następny projekt o nazwie „Sport i turystyka bez granic - wzmacnianie partnerskiej współpracy gmin”, na który wydatki ograniczały się do kosztów organizacyjnych oraz nakładów na sprzęt, realizowało Olecko w roku 2014 z trzema litewskimi samorządami (gminy: Wilkowyszki, Kozlu Ruda oraz rejon Alytus). Tym razem zorganizowano minimundial, obóz pływacki i zawody lekkoatletyczne (Mieszuk, 2015). Trudno przecenić znaczenie tych wszystkich przedsięwzięć, wspólnie realizowanych przez Olecko i jego litewskich partnerów, dla poznawania się i nawiązywania współpracy, a także budowania sympatii pomiędzy ich uczestnikami. Powszechnie wiadomo, że kultura i sport są sferami życia społecznego, w ramach których procesy te przebiegają najintensywniej, a ich efekty są najbardziej autentyczne i trwałe.

Następny zagraniczny partner Olecka, Rosyjski Gusiew, to miasto leżące na północny zachód od Olecka, w obwodzie kaliningradzkim. Umowę o współpracy podpisano 18 czerwca 2004 roku. Była ona konsekwencją kontaktów samorządowych burmistrza Olecka, Wacława Olszewskiego, który jeszcze w latach 90. ubiegłego wieku kontaktował się z przedstawicielami Gusiewa jako ówczesny (w latach 1994-1998) przewodniczący sejmiku samorządowego województwa suwalskiego. Treść tej umowy jest bardzo podobna do tych podpisanych ze 
Szczuczynem czy z Wilkowyszkami. Nie ma w niej jednak cytowanego wcześniej fragmentu dotyczącego spraw ideowo-politycznych. Dokument ten zawiera sformułowany przez stronę polską priorytet - jest nim kultura i problematyka z nią związana. Dzięki podpisaniu tego porozumienia Olecko mogło pozyskać środki unijne na realizację projektu „Akademia Kultury, Tradycji i Współczesności Olecko - Aktivio”. W ramach przygotowań do merytorycznej realizacji tego przedsięwzięcia wyremontowano siedzibę Regionalnego Ośrodka Kultury w Olecku „Mazury Garbate”, w którym projekt ten był realizowany. W związku $\mathrm{z}$ tą umową Olecko pozyskało dofinansowanie na rozbudowę infrastruktury oświatowo-sportowej (sala gimnastyczna), budowę ulicy czy rozbudowę na obszarach wiejskich istniejącej sieci wodociągowej i kanalizacyjnej. Specjalnego wymiaru nabrała współpraca Olecka z Gusiewem w unijnym okresie planistycznym 2007-2013 (projekty realizowane $\mathrm{w}$ ramach tej agendy i przewidzianych dla niej środków finansowych były - zgodnie z unijną praktyką - realizowane z dwuletnim „poślizgiem”, a więc do końca roku 2015). To wtedy, wspólnie z litewskim samorządem Kozlu Rudy (Kozłowa Ruda), zawarto trójstronną umowę partnerską na wspólną realizację projektu „Partnerstwo na rzecz ochrony wód obszaru transgranicznego Litwy, Polski i Rosji”. Zakładał on kompleksową realizację inwestycji infrastrukturalnych na terenie gminy Olecko, mających na celu poprawienie sieci urządzeń służących gospodarce wodno-kanalizacyjnej. $\mathrm{W}$ jego ramach zbudowano nowe wodociągi i kanalizację. Analogiczne prace zostały wykonane na terenie litewskiego i rosyjskiego partnera stolicy Mazur Garbatych (Mieszuk, 2015).

Kolejnym zagranicznym partnerem Olecka jest ukraiński Drohobycz - podpisanie umowy partnerskiej nastąpiło 1 grudnia 2005 roku. Był to wynik działań władz Olecka, które za pośrednictwem zaprzyjaźnionych mieszkańców Lwowa poszukiwały miasta ukraińskiego, z którym mogłyby nawiązać bliźniaczą współpracę. Olecczanom chodziło o znalezienie miejskiego partnera, zamieszkiwanego w istotnej części przez ludzi mających polskie korzenie i którego historia ma związki z Polską i polskością. W związku z tym, że władze Drohobycza były zainteresowane współpracą z polskim Oleckiem, doszło do podpisania wspomnianej umowy. Znalazł się w niej zapis analogiczny jak w umowach z Wilkowyszkami i Szczuczynem, dotyczący wzajemnego szanowania odrębności ideowo-historycznych. Zapowiadano, podobnie jak w pozostałych przypadkach, organizowanie wymian różnego rodzaju środowisk ze społeczności lokalnej. W omawianym porozumieniu podkreślono, że strony zamierzają wspólnie uczestniczyć w realizacji projektów finansowanych z programów ogólnokrajowych i zagranicznych. 
Szczególnie wyeksponowano zainteresowanie problematyką odnawialnych źródeł energii elektrycznej oraz rozwojem obszarów wiejskich. Zapowiadano także organizowanie różnego rodzaju spotkań, konferencji i seminariów mających służyć wymianie informacji i wiedzy, w tym przede wszystkim dotyczących tych dwóch sfer aktywności władz lokalnych. W praktyce współpraca z Drohobyczem została zdominowana przez problematykę polonijną i kontakty z mieszkańcami Drohobycza przyznającymi się do polskich korzeni. W roku 2006 delegacja polska wzięła udział w odsłonięciu odnowionego Grobu Nieznanego Żołnierza. Wielokrotnie spotykano się z władzami Towarzystwa Kultury Polskiej Ziemi Lwowskiej i przedstawicielami polonii. Spektakularnym przykładem takiego sprofilowania tych kontaktów była przeprowadzona w roku 2009 akcja „Znicz”. Polegała na tym, że władze Olecka zorganizowały dostarczenie na Ukrainę, do Lwowa i w jego okolice, zniczy. W Święto Zmarłych zapalili je na polskich grobach przedstawiciele zamieszkujących ziemię lwowską środowisk polskich, głównie tamtejsi harcerze. Całość tego przedsięwzięcia była możliwa dzięki podarowaniu przez olecką firmę „Znicz” ogromnej ilości lampek nagrobnych. O ich ilości świadczy to, że musiały one zostać dostarczone na Ukrainę dużym samochodem ciężarowym. Było więc to przedsięwzięcie daleko wykraczające poza współpracę dwóch niewielkich miast, nie tylko w wymiarze geograficznym, ale także patriotyczno-symbolicznym.

Deklarowane w umowie z Drohobyczem, ale w praktyce nierealizowane, zainteresowanie Olecka problematyką ekologicznych i odnawialnych źródeł energii legło u podstaw porozumienia $\mathrm{z}$ kolejnym partnerem - austriackim Guessingiem. Doszło ono do skutku w wyniku wizyty studialnej zastępcy burmistrza Olecka Henryka Trznadla, który odwiedził to miasto, aby zapoznać się z funkcjonującymi na jego terenie odnawialnymi źródłami energii elektrycznej. W konsekwencji 19 kwietnia 2006 roku podpisano porozumienie partnerskie pomiędzy oboma gminami. Umowa ta ma zbliżony kształt do innych, wcześniej podpisanych przez Olecko. Jest w niej mowa o zacieśnianiu więzi pomiędzy dwoma krajami na szczeblu państwowym, o organizowaniu wymian różnego rodzaju środowisk ze społeczności lokalnych, o wzajemnym wymienianiu się wiedzą samorządową, szczególnie zaznaczając jako obszar współdziałania problematykę energii odnawialnej, transfer technologii i wiedzy. Znajdujemy w niej fragment dotyczący wzajemnego poszanowania odrębności ideowo-politycznej, analogiczny jak w umowach ze Szczuczynem, Wilkowyszkami czy Drohobyczem, a którego nie ma w umowie z Gusiewem. Porozumiewające się strony zapowiadają współpracę we wspólnym pozyskiwaniu zewnętrznego finanso- 
wania wspólnych projektów oraz przygotowywanie „konferencji, seminariów i warsztatów roboczych". Postanowienie to szybko doszło do skutku, bowiem już w maju 2006 roku doszło do zorganizowania interesującego spotkania. W murach Wszechnicy Mazurskiej - nieistniejącej już dzisiaj oleckiej uczelni niepublicznej (Wszechnica Mazurska w Olecku była niepubliczną uczelnią wyższą działającą w latach 1992-2013) - został zorganizowany Międzynarodowy Kongres Energii Odnawialnej, na którym spotkali się samorządowcy, przedsiębiorcy i naukowcy zajmujący się ekologicznymi źródłami energii odnawialnej. Przedsięwzięcie to stanowiło przejaw cennego dla władzy publicznej oraz biznesu i nauki wzajemnego przenikania się ich aktywności. Współpraca taka ułatwia przenoszenie efektów badań naukowych do praktyki życia społeczno-gospodarczego i nosi w ekonomii nazwę sprzężenia zwrotnego, zjawiska pożądanego, jednak rzadko spotykanego. W tym przypadku mającego dodatkowo wymiar międzynarodowy, bowiem Olecko wzięło na siebie ciężar organizowania tej współpracy także na rzecz swoich zagranicznych partnerów samorządowych, stając się podmiotem animującym współpracę międzynarodową w dziedzinie ekologicznych źródeł energii. W rok po omawianym Kongresie, w maju 2007 roku odbyło się w Olecku spotkanie jego władz z potencjalnymi inwestorami z Austrii, poświęcone ewentualnemu zbudowaniu w stolicy Mazur Garbatych fabryki biopaliwa i opartej na nim ciepłowni. W kilka miesięcy później delegacja Olecka zwiedzała w austriackim Klagenfurcie fabrykę biopaliwa, przekonując jej kierownictwo do zainwestowania w Polsce i stworzenia w Olecku podobnego zakładu. Rozmowy w tej sprawie były jeszcze kontynuowane w roku następnym w Polsce, ale ostatecznie nie doszło do ich sfinalizowania decyzją o budowie ekologicznego zakładu energetycznego w Olecku (Mieszuk, 2015).

Następny partner zagraniczny Olecka to estońskie Johvi. Umowę z nim zawarto 25 maja 2006 roku. Jej treść stanowi praktycznie kopię dokumentu podpisanego $\mathrm{z}$ austriackim Guessingiem. Geneza nawiązania tego kontaktu była zupełnie inna. $Z$ inicjatywą podjęcia współpracy tym razem wystąpił partner zagraniczny Olecka. Przedstawicielka Estonii w Komitecie Regionów Unii Europejskiej Anne Ly Reimaa zauważyła Olecko jako gminę aktywną na arenie międzynarodowej i wystąpiła z propozycją, aby jej rodzinne Johvi podjęło współpracę z Oleckiem. Do podpisania stosownego dokumentu doszło bardzo szybko, ponieważ strona polska była tą współpracą zainteresowana, a przewodniczącym rady miejskiej Johvi był mąż Anne Ly Reimaa, Vello. Takich samorządowych porozumień estońsko-polskich jest tylko kilka. Nie jest to bowiem główny kierunek zainteresowań polskich samorządowców, a Estonia jest krajem bardzo 
małym i w związku z tym nie ma zbyt wielu potencjalnych partnerów samorządowych (na temat tego, jakie samorządy terytorialne i z jakich krajów stanowią główne zainteresowanie polskich samorządowców, patrz: S. Faliński, 2011). Dziedziną dominującą w stosunkach Olecka z Johvi jest kultura - wzajemna wymiana różnego rodzaju delegacji i zespołów trwa od momentu podpisania porozumienia. Goście z Estonii biorą udział w oleckich imprezach kulturalnych, jak na przykład „Przystanek Olecko”, zaś olecczanie wyjeżdżają do Johvi. W 2007 roku przedstawiciele Olecka wzięli udział w zorganizowanym w Johvi Festiwalu Kultur.W rok później Szkolna Orkiestra Kameralna Państwowej Szkoły Muzycznej I stopnia w Olecku koncertowała podczas Festiwalu Dziecięcego z okazji Dnia Dziecka w Johvi oraz brała udział w Festiwalu Instrumentów Strunowych w Szkole Artystycznej w Ahtme. Z kolei rok później odbył się w Olecku wspólny koncert muzyczny Estończyków i Polaków grających odpowiednio w John Music School Big Band i w Orkiestrze Kameralnej Państwowej Szkoły Muzycznej w Olecku. Różnego rodzaju spotkania i wymiany obywateli Olecka i Johvi odbywają się na bieżąco. Okazją do takich wzajemnych odwiedzin są święta miejskie i państwowe. Ta aktywność zagraniczna Olecka i olecczan jest wysoko oceniana i propagowana przez polskie władze państwowe. Wyrazem tego było w 2014 roku zaproszenie przez ambasadora Polski delegacji oleckiej na organizowane w Estonii obchody 223. rocznicy uchwalenia Konstytucji 3 maja i na Festiwal Kultury Polonii Estońskiej (Mieszuk, 2015).

Najpóźniej zawartym porozumieniem dwustronnym Olecka jest umowa z litewską Kozlu Rudą, czyli Kozłową Rudą. Dokument ten podpisano 15 sierpnia 2011 roku jako rozwinięcie realizowanej wcześniej współpracy w ramach projektów współfinansowanych przez Unię Europejską. Dokument jest zupełnie inaczej skonstruowany niż wcześniejsze. Charakterystyczna jest terminologia, akcentująca fakt, że jest to porozumienie dwóch (pisanych dużą literą) Samorządów i reprezentujących je burmistrzów. Nie umieszczono zapisu wpisującego porozumienie w stosunki pomiędzy Polską a Litwą. Jest to umowa pomiędzy dwoma leżącymi w różnych państwach samorządami nieuwikłanymi w stosunki na poziomie państwowym. Świadczy to o większym poczuciu odrębności lokalnej i względnej niezależności terytorialnej. To również dowód na ewolucję tego poczucia wśród władz obu wspólnot gminnych, a być może także wśród ich mieszkańców. Także cel, jakiemu ma służyć ta umowa, został określony w inny, bardziej uniwersalny sposób. Jest tam zawarty zapis o wszechstronnym rozwoju obu wspólnot i zacieśnianiu kontaktów między nimi (w tekście wielokrotnie powtórzono termin „samorząd”). Mimo uniwersalnego charakteru tego 
dokumentu wskazano w nim także obszary szczególnego zainteresowania obu partnerów, akcentując wspólne pozyskiwanie środków unijnych, gospodarkę komunalną, ochronę zdrowia i środowiska, oświatę, kulturę, sport, pomoc społeczną, zwalczanie bezrobocia oraz porządek i bezpieczeństwo publiczne. Bardzo słusznie za najbardziej efektywną formę współpracy uznano bezpośrednie kontakty władz oraz członków obu wspólnot lokalnych. W omawianej umowie podkreśla się otwartość obu stron na ewentualne udoskonalanie zapisów treści umowy na inne niż w niej określone dziedziny i formy współpracy.

Poza oficjalnymi kontaktami władz współpraca pomiędzy Oleckiem i Kozłową Rudą ma przede wszystkim wymiar projektowy. To wspólnie z tą gminą Olecko przeprowadziło najwięcej przedsięwzięć opartych na finansowaniu zewnętrznym. Projekty takie były realizowane (z przeważającym udziałem środków Unii Europejskiej) w ramach perspektywy 2007-2013. Dotyczyły one ekologii, sportu, kultury, tradycji lokalnej każdego z partnerów osobno i wspólnej obojgu oraz atrakcyjności turystycznej, ale także wzbogacania infrastruktury technicznej obu gmin poprzez rozbudowę sieci wodociągów i kanalizacji (problematykę dotyczącą współpracy w zakresie wspólnej budowy infrastruktury technicznej Olecka i Kozłowej Rudy omówiono wcześniej, przedstawiając współpracę Olecka z rosyjskim Gusiewem, która w części jest trójstronna: Olecko - Gusiew - Kozłowa Ruda). Jeszcze przed podpisaniem omówionego porozumienia partnerskiego z 2011 roku, pomiędzy marcem a sierpniem 2010 roku, oba samorządy realizowały w ramach Programu Współpracy Transgranicznej Litwa - Polska projekt noszący tytuł „Nasze małe ojczyzny w harmonii z przyrodą". W jego ramach przy jednej ze szkół podstawowych oleckiej gminy (w Gąskach) zagospodarowano nieużytki rolne i utworzono minipark służący edukacji przyrodniczej i ekologicznej uczących się tam dzieci, także niepełnosprawnych, bowiem szkoła ma oddziały integracyjne. Osiągnięto to poprzez rekultywację terenu, jego odwodnienie i adaptację oczka wodnego, wytyczenie alejek i posadzenie roślinności oraz zainstalowanie małej architektury ogrodowej. Podobna inwestycja została zrealizowana w Kozlu Rudzie. Dzięki tym obiektom było możliwe rozwinięcie edukacji ekologicznej młodych obywateli obu gmin. W 2010 roku, od marca do grudnia, przeprowadzono prace składające się na projekt „Z boiska na igrzyska”. Podobnie jak poprzedni zorientowany był na dzieci i młodzież. Na terenie polskiej gminy wyremontowano salę gimnastyczną (malowanie ścian, wymiana świetlenia, okien i drzwi, renowacja posadzki, zakup wyposażenia) i zmodernizowano boisko szkolne (odtworzenie powierzchni trawiastej i montaż bramek). Podobne prace przeprowadzono u partnera litew- 
skiego, gdzie zorganizowano mini olimpiadę, w której brali udział młodzi Litwini oraz Polacy. Kolejny, realizowany wspólnie przez Olecko i Kozlu Rudę projekt był otwarty dla wszystkich grup wiekowych zamieszkujących obie gminy, a także gości spoza nich. Stanowił element Europejskich Dni Dziedzictwa Kulturowego „Legendy ożywają i dziś”; był nastawiony na zaprezentowanie przez stronę polską i litewską własnych oraz wspólnych składników tradycji historycznych. W Olecku odbyła się sesja naukowa poświęcona tej tradycji. Zorganizowano również happening historyczny nawiązujący do powstania Olecka. Stworzono „wioskę średniowieczną”, prezentującą, jak żyli ludzie w wiekach średnich - zwiedzający mogli wziąć udział w różnego rodzaju grach i konkursach poświęconych ówczesnym obyczajom i zachowaniom. Można też było obejrzeć walki podczas turnieju rycerskiego oraz spróbować regionalnych potraw, wziąć udział w warsztatach kulinarnych i nauczyć się przygotowywania tradycyjnych potraw. Dla upamiętnienia realizacji tego programu zasadzono specjalny, upamiętniający współpracę transgraniczną szpaler drzew. Podobny charakter miał realizowany w 2011 roku projekt „W czasach rycerzy i legend - jarmark średniowieczny”, przy czym finansowano go z Norweskiego Mechanizmu Finansowego. Celem jarmarku było zwiększenie zainteresowania olecczan własną przeszłością i pobudzenie ich do działań mających na celu pielęgnowanie przeszłości i tradycji, przede wszystkim tej lokalnej i regionalnej oraz budowanie przez to swojej wspólnotowości. Jarmark zorganizowano w Olecku. Podczas niego można było wziąć udział w warsztatach walki na miecze i tarcze, a także obejrzeć turniej rycerski. Na jarmarku tym brzmiała muzyka średniowieczna, przygotowywano stare potrawy, prezentowano tradycyjne wyroby rzemieślnicze i zrekonstruowane przedmioty codziennego użytku. W festynie wzięli udział przedstawiciele Kozłowej Rudy. Omówione wcześniej porozumienie podpisano 15 sierpnia. Od marca 2011 roku do stycznia roku 2012 realizowano projekt o nazwie „Budowa wspólnego produktu turystycznego regionów Olecka i Kozłowej Rudy na bazie rozwiniętej infrastruktury turystycznej”. W jego ramach w polskiej gminie powstało obozowisko wyposażone w bogatą infrastrukturę techniczną, na którą złożyły się instalacje sanitarna i elektryczna, oświetlenie i ogrodzenie. Wybudowano budynek socjalno-sanitarny, utwardzono wyodrębnione powierzchnie, powstały ciągi piesze i jezdne. W gminie litewskiej stworzono i wyposażono park linowy. Wspólnie zaś prowadzono turystyczną akcję promocyjną, mającą zachęcić przybyszy do odwiedzenia obu gmin i skorzystania z walorów turystycznych Olecka i Kozlu Rudy, w tym rekreacyjnego wykorzystania powstałych w ramach tego projektu obiektów. 
Współpraca międzynarodowa Olecka nie sprowadza się wyłącznie do przedstawionych umów partnerskich, ale także do ich realizacji na poziomie obywatelskim, na którym współpracują ze sobą bezpośrednio obywatele, budując więzi nie tylko pomiędzy instytucjami, ale także między członkami wspólnot lokalnych. Specyficzna i bardzo cenna jest współpraca aktualnych olecczan z byłymi olecczanami czy raczej treuburczykami, czyli mieszkańcami Olecka z czasów, kiedy nazywało się ono Treuburg i należało do Niemiec. Ze strony niemieckiej podmiotem tej niesformalizowanej odpowiednim dokumentem współpracy jest Stowarzyszenie Treuburczyków. Polega ono na utrzymywaniu bieżącej współpracy pomiędzy Stowarzyszeniem a polskimi władzami samorządowymi, przejawiającej się między innymi udziałem polskich samorządowców - nie tylko z gminy Olecko, ale także z powiatu oleckiego - w dorocznych, odbywających się w Niemczech zjazdach treuburczyków. Współpraca ta sięga jeszcze czasów, kiedy Polska nie była członkiem Unii Europejskiej. Najbardziej spektakularnym przejawem tej współpracy było zrealizowane w 2003 roku, współfinansowane przez obie strony, wyremontowanie oleckiego cmentarza ewangelickiego i przeniesienie $\mathrm{z}$ centrum miasta pomnika. Jego losy symbolicznie unaoczniają przemiany, jakie nastąpiły w ciągu ostatnich dziesięcioleci w Olecku, Polsce i Niemczech oraz w naszych wzajemnych relacjach. W czasach kiedy Olecko nazywało się Treuburg, stał on w centrum miasta i zwieńczał go niemiecki orzeł, po roku 1945 była to gwiazda, po 1989 ustawiono na nim polskiego orła w koronie. Zmieniały się także tablice znajdujące się na tym monumencie, ich treść i język. Ostatecznie pomnikowi przywrócono pierwotny kształt i przesłanie po jego przeniesieniu na wyremontowany cmentarz ewangelicki. Takie załatwienie sprawy pomnika jest świadectwem i dowodem na to, jak olecczanie podchodzą do swojej przeszłości - nie tylko chcą, ale także potrafią układać swoje stosunki z dalszymi i bliższymi sąsiadami. Sami przecież są w znaczącej części przesiedleńcami i ich potomkami. Wielu z nich groby swoich przodków pozostawiło we wsiach i miastach, które dzisiaj są poza Polską i noszą inną nazwę.

Podsumowując współpracę międzynarodową Olecka, trzeba wspomnieć o uzyskaniu przez tę gminę wysokiego i znamiennego wyróżnienia, będącego wyrazem docenienia współpracy na arenie europejskiej. Otóż w roku 2014 ten samorząd jako jedyny w Polsce uzyskał tytuł Europejskiego Miasta Sportu 2015. To prestiżowe wyróżnienie nadaje Europejskie Stowarzyszenie Stolic Sportowych za rozwój infrastruktury sportowej oraz popularyzację zdrowego stylu życia wśród mieszkańców. Ta honorowa nagroda jest przyznawana w dwóch kategoriach: miasta do 25 tysięcy mieszkańców mogą uzyskać taki tytuł, jaki 
zdobyło Olecko, a powyżej tej liczby tytuł Europejskiej Stolicy Sportu, który w 2008 roku uzyskała Warszawa. Bez żadnej wątpliwości wyróżnienie to mogło uzyskać Olecko w znaczącej, jeżeli nie decydującej części, w następstwie swojej współpracy międzynarodowej. Jak pamiętamy, sport - szczególnie wśród dzieci i młodzieży - to jedna z najważniejszych dziedzin życia, które rozwijają się w Olecku dzięki jego aktywności na arenie międzynarodowej. To także dzięki współpracy międzynarodowej powstała w gminie Olecko bogata baza dla uprawiania sportu i rekreacji.

\section{PODSUMOWANIE}

Starając się udzielić odpowiedzi na postawione na wstępie pytanie - co i w jakim stopniu zdecydowało o takim a nie innym kształcie współpracy międzynarodowej miejsko-wiejskiej gminy Olecko? - przede wszystkim trzeba stwierdzić, że był to system wzajemnie przenikających się i oddziałujących na siebie czynników. Można je podzielić na obiektywne i subiektywne. Wśród obiektywnych najpierw trzeba wymienić położenie geograficzne gminy, które może przesądzać o otoczeniu międzynarodowym, w jakim funkcjonuje gmina. Władze gminy mogą to położenie wykorzystywać w mniejszym bądź większym stopniu, zawsze jednak wpływa ono na możliwości aktywności międzynarodowej konkretnej wspólnoty lokalnej. W przypadku Olecka mamy do czynienia z bardzo dobrym wykorzystaniem położenia geograficznego. W tym momencie pojawia się drugi czynnik obiektywny, oddziałujący na potencjalną współpracę zagraniczną wspólnoty lokalnej, czyli konkretny (powiązany z położeniem geograficznym) moment historyczny. Olecko nawiązało swoją współpracę z francuskim Marly na początku lat 70. ubiegłego wieku, kiedy Polska Ludowa otwierała się na Zachód, przede wszystkim na Francję. Po roku 1989 Olecko mogło nawiązać współpracę z miastami kiedyś leżącymi w Polsce, a teraz znajdującymi się na odzyskującej niepodległość i budującej demokrację Białorusi, na niepodległej Litwie czy na Ukrainie. W czasach komunistycznych było to mało realne, tak jak przestało być realne w odniesieniu do odchodzącej od demokracji w latach 90. ubiegłego wieku Białorusi. To wreszcie polskie członkostwo w Unii Europejskiej stworzyło koniunkturę dla współpracy międzynarodowej polskich samorządów terytorialnych, szczególnie zaś tych znajdujących się na obszarach geograficznych objętych specjalnymi programami rozwojowymi. Oddziałują więc oba czynniki - geografia i moment historyczny - składające się na geopolitykę (na temat 
geopolityki patrz przede wszystkim: Moczulski, 2010). Kolejnym czynnikiem obiektywnym jest kształt społeczności lokalnej, jej pochodzenie i tradycje - jak pamiętamy, olecczanie to w istotnej części przesiedleńcy bądź ich potomkowie, stąd historyczno-sentymentalna motywacja nawiązania współpracy ze Szczuczynem, Wilkowyszkami, Kozłową Rudą czy Drohobyczem. Istotne znaczenie ma tutaj stosunek konkretnej społeczności do innych, jej otwartość na świat lub obawa przed nią, jej poczucie wartości, wzajemne zaufanie i kapitał społeczny. To przecież ta konkretna społeczność wybiera swoich przedstawicieli, mających określone nastawienie do współpracy międzynarodowej. W przypadku Olecka bardzo szczególne, ponieważ burmistrz gminy pełni tę funkcję nieprzerwanie od kilku kadencji, a jego działania w zakresie współpracy międzynarodowej są znane. Także w sprawach dotyczących kontaktów międzynarodowych oraz kontaktów z innymi wspólnotami lokalnymi podmiotem pierwotnym jest konkretna wspólnota terytorialna, przesądzająca o tym - choć nie bezpośrednio - czy, z kim i jakie relacje będą nawiązywane na arenie międzynarodowej.

Warunki i możliwości określone czynnikami obiektywnymi mogą być wykorzystane, jeżeli będą pozytywnie oddziaływać czynniki subiektywne. Podstawową kwestią w tym kontekście wydaje się to, kto rządzi gminą. Czy jest to zwolennik współpracy międzynarodowej? Czy jest kompetentny, to znaczy czy potrafi wykorzystać istniejące obiektywnie możliwości? W przypadku Olecka na oba pytania możemy odpowiedzieć pozytywnie. Wręcz wydaje się, że istniejące, stworzone przez położenie geograficzne i programy unijne warunki zdeterminowały dużą część współpracy międzynarodowej Olecka, które wykorzystało bardzo dobrze tę koniunkturę, rozwijając współpracę projektową ze swoimi partnerami z Litwy i Rosji. Można wręcz postawić tezę, że współpraca międzynarodowa Olecka ma co najmniej w połowie charakter projektowy. Wskazuje to również, jak budowanie więzi między wspólnotami lokalnymi może być i jest animowane przez Unię dzięki konkretnym, ściśle osadzonym geograficznie programom. Nie byłoby to jednak możliwe, gdyby nie otwarty na innych, tolerancyjny i poszukujący porozumienia oraz współpracy z dalszymi i bliższymi sąsiadami charakter olecczan.

\section{BibLIOGRAFIA:}

Barber, B.R. (2014). Gdyby burmistrzowie rzadzili światem. Dysfunkcyjne kraje, rozkwitajace miasta. Warszawa: MUZA S.A.

Faliński, S. (2011). Współpraca międzynarodowa samorządów terytorialnych. W: Wymiana i konkurencja. Środowisko i formy promocji Polski $w$ świecie, „Studia 
i analizy dyplomacji kulturalnej i publicznej”, nr 2. Warszawa: Collegium Civitas i Instytut Adama Mickiewicza.

Mieszuk, A. (2015). Wykaz miast partnerskich, z którymi gmina ma podpisane umowy partnerskie od 1960 r. oraz zakresy współpracy. Olecko (na prawach maszynopisu). Moczulski, L. (2010). Geopolityka. Potega w czasie i przestrzeni. Warszawa: Bellona.

Porozumienie o stałej współpracy Samorządów: Gminy Olecko (Polska) i Gminy Kozlu Ruda (Litwa). Archiwum Zakładowe Urzędu Miejskiego w Olecku.

Porozumienie zawarte w dniu 26.11.1975 r. między Merem miast Marly i Przewodniczacym Miejskiej Rady Narodowej Olecka w sprawie współpracy obu miast. Archiwum Zakładowe Urzędu Miejskiego w Olecku.

Rozmowa przeprowadzona przez autora z zastępcą burmistrza Olecka Henrykiem Trznadlem 20.10.2015 roku.

Rozmowa przeprowadzona przez autora z burmistrzem Olecka Wacławem Olszewskim 19.10.2015 roku.

Umowa o współpracy Gminy Olecko (Polska) z Gmina Johvi. Archiwum Zakładowe Urzędu Miejskiego w Olecku.

Umowa o współpracy gminy Olecko z miastem Drohobycz (Ukraina). Archiwum Zakładowe Urzędu Miejskiego w Olecku.

Umowa o współpracy gminy Olecko (Polska) z miastem Gusiew (Rosja). Archiwum Zakładowe Urzędu Miejskiego w Olecku.

Umowa o współpracy gminy Olecko (Polska) z miastem Gussing. Archiwum Zakładowe Urzędu Miejskiego w Olecku.

Umowa o współpracy miast Olecko - Szczuczyn. Archiwum Zakładowe Urzędu Miejskiego w Olecku.

Umowa o współpracy miast Olecko - Viłkawiszki. Archiwum Zakładowe Urzędu Miejskiego w Olecku. 